\title{
Factors That Influence Social Sciences University Students' Ability in Learning English to Face International Competiveness In 4.0 Era
}

\author{
Meladina $^{1 *}$ and Hendra Putra ${ }^{2}$ \\ 1 *STIKes Fort De Kock, Bukittinggi, Indonesia, $ه$ (email), melaadina@gmail.com. \\ ${ }^{2}$ STIKes Fort De Kock, Bukittinggi, Indonesia, $ه$ (email), hendraputra@fdk.ac.id
}

\begin{abstract}
Lack of English language ability in this 4.0 era is a serious problem. English is an International language which is used by every country, even though in those countries do not use English as their first language. Furthermore, in this era, people are expected to have acknowledged of English in order to be competitive both in Indonesia and Internationally. It is difficult for a human to live without communicating with others. The type of this research was descriptive quantitative. The participants were 107 of Guidance and Counseling study program students in IAIN Bukittinggi. By using simple random sampling technique, 74 students had been chosen as the samples. From the result of this research, it was that found 40 of them had positive motivation in learning English, 34 of the respondents had lack of motivation, 27 of them had a good perception and 38 of the respondents stated that that they were less capable in mastering skills in English. In short, perceptions and motivation possessed by students greatly influenced their abilities. From this research, the students' perceptions were lack of use of English so that it was a big impact on their ability to use English. In other words, students' motivation and perception may influence students' ability in learning English. Lack of English ability may influence they readiness to face the international competiveness in 4.0 eras.
\end{abstract}

Keywords: Motivation, Perception, English Ability, International Competitiveness and 4.0 Eras

\section{INTRODUCTION}

Lack of English ability in this era is a serious problem. English is regarded as the International language used by every country even though they do not use English as their native language. In Indonesia, English is not the main language. English is considered a foreign language. It means that, it hard to find someone who uses English in their daily life -they only use it in certain context. According to Sumardi in (Pendahuluan, n.d.), if a student tries to learn a foreign language, the goal is to be able to comprehend that language fluently and correctly and they expect that they will use that language to communicate with others. In short, foreign language is very important for them, their own group and the local community.

Indonesian is the official language while their local language is used in the informal sector. However, in every level of school, from elementary school until college, English is a priority subject to study. However, in the work field the employee will not use English for communication. Only few institutions, factories and work fields use English as the main language for communication. This ensures that practical English is limited. Many efforts are planned and done by the government to improve communities' ability in English. However, it seems that it has not had any significant impact with increasing the ability of English in the Indonesian community.

Meanwhile, we cannot reject that nowadays everyone who wants to connect with the international community should be able speak, write and understand English. Furthermore, in this era of globalization, people are expected to have knowledge and skills to equip them with the ability to compete internally and externally. One of the skills is mastering a language. A language is the tool for communication between people. If someone is able to comprehend more than one language, it is easier for her/him to explore and research information. Language is a basic need for humans (Wardah, 2017). It means that it is difficult for a human to live without communicating with others. Through language they can express their feelings, thoughts and find information based on their interests or profession.

In the area of education, English as an important subject that should be learnt by students commencing in elementary school until university. University has a role to produce good human resources who will be proficient to be involved internationally. It is supported by (Santosa, 2018)who stated that university is one of the educational institutions that has a responsibility to do good quality teaching and learning process in order to create graduates 
based on requirements. One of the requirements is by mastering English. In a university level, especially for guide and canceling study program, English as a general subject that should be learnt. All of the students should enroll in this subject which has 2 credits a week in the eighth semester. On completion of this study all of the students are able to use English in their daily life based on thy field of study. Moreover, it is expected of them to read many sources related to their topic. Consequently, they have language to write scientific papers in English in order to present it by using English.

However, based on the initial survey, majority of students found difficulties in learning English. They thought that English is very difficult to learn and master. This case is in line with (Kesehatan, 2010) research finding. She wrote that most of the students in a university found it hard to understand the lecturer's instruction and found difficulties in comprehending basic English such as reading an English passage, listening, speaking and writing. Even though they had already learnt it for many years they could not master it well. From this case, it is known that there are many problems faced by the student that makes it hard for them to understand English well.

Besides, in order to improve students' ability to learn anything, they have to have motivation. Motivation is one of the most important things to consider achieving a goal. It is also expressed by (Santosa, 2018)that in teaching and learning process, motivation is needed. If a student does not have motivation, they do not want to learn In short, motivation in learning English is the students' willingness to learn English well. It can be achieved if they need to learn that language and they know that it is useful for them in their daily life.

Motivation increases students will to learn. This statement is supported by Wingkel and Hastuti in (Rhepon, 2014)who stated that motivation in learning is the effort the students put into a subject to make them want to learn. They have concluded that no one can teach students to comprehend anything unless they have the motivation to put in the effort to understand new learning. Students also have a personal commitment to always try and improve. Furthermore, motivation may affect someone's effort. According to Ruhama (2012), motivation comes from one's internal factor. It can be seen by their attitude and affective condition in learning anything, for example English. It means that, if the student has motivation in learning English, they will put in the effort required to comprehend it as one of their tools of communication.

In short, motivation in learning English is an individuals' effort to understand and comprehend the language and have the commitment to be always try in order to achieve the goal. The goal of learning a language, in this case English, is to communicate with others using English.

Every body's perspective is different. It is supported by Muntamah (2012) who expressed that someone's perception about an object is not the same. It is influenced by subjective feelings. It means that, every different perception or opinion depends on someone's subjective feelings. Subjective feelings include motivation, interest, experience and hope (Joballis, 2000)

Basically, ability in English is the skill required to master English. To become proficient in English, students must continue to work on the skills required to overcome problematic issues with listening, speaking, writing and reading in order to be able to express themselves in English when required.

Moreover, by mastering English, an individual may compete in the international or global zone. According to Haque in (Arslan \& Tathdil, 2012)competitiveness is the ability of someone to produce goods or services that are appropriate with international requirements. This ensures that an individual will have continuous real income and improve the level of his/her welfare. It means that, someone may have competitiveness if they able to produce something that is very useful to increase their economic status. International or global competitiveness is not only related to world economics. It also includes the country's education system. Based on (Sahlberg, 2006) in order to compete in economic competitiveness, the country should increase the standardization of teaching and learning. It may be done by implementing networking among countries, deeper cooperation and sharing ideas in all levels of education. It means that, improving someone economic status may be done by concentrating on the quality of teaching and learning or education system.

Developing international networks and collaborative cooperation is mutually beneficial for respective countries. In order to cooperate and share ideas and concepts, they have to communicate in a language that is acceptable to each country. It is preferable to communicate in English which is considered the International language. Because of this reason, in the education system (teaching and learning process), educators are encouraged to teach and learn English in order to share and communicate with others. By doing that, indirectly they can compete in the international arena

Furthermore, (Reddy, 2016)explains that English as the International language plays an important role in today's world. There are many aspects in an individual's daily life where English is spoken, such as business, education, applying for a job, seeking information, media and entertainment, and for international relation. In education, tertiary students use English as medium of instruction in most universities and higher education institutions of world class. Then, in getting a job and better salary, English is very useful. Multinational business organizations will ask the employee to have international connections Employees are expected to know and be able to share their ideas with others by using English. People who work abroad also need to know English. English proficiency with encourage individuals to network overseas that will be beneficial for their company.

To be brief, international competitiveness is the ability in to compete internationally. The expectation is to not only produce a product or service that may increase an individuals' income and living standard, but, also a change in the education system with a focus on studying the 
international language, English. English plays an important role in an individuals' life. It is hard for a person to have a good education, employment, information and international relations without mastering English. By mastering English, they can collaborate, share ideas, receive better salary and network in order to be able to compete with the countries around the world and fulfill today's world needs.

Furthermore, IAIN Bukittinggi is one of the biggest universities in Bukittinggi. The target of this university is producing graduates which are able to compete globally and internationally. One of the ways to compete competitively in the international arena is by mastering the international language (English). Even though they comes from social sciences (Guide and Counseling study program), they have to be able to communicate in English. By using English, they can do a collaboration to share current issues related to that study of the field with international area. Moreover, graduates also can also apply for a job abroad because they can competently communicate with others in English, which is regarded as the International language. In this respect, studying English should be regarded as an essential basic skill.

Guide and Counseling Study Program at the third year level in IAIN Bukittinggi has 107 students. They are required to learn English at their first year. It has been planned by the institution in order to achieve the vision to produce graduates capable to compete globally and internationally. This research was conducted in order to know to the students' motivation, perception and ability related to English proficiency. By doing this, it is expected that university will design programs, materials and teaching and learning process based on students' need in order to be prepared to face some obstacles in the future or international competitiveness.

\section{METHOD}

The research method was descriptive quantitative research method. The respondents were all students in Guide and Counseling Study Program. Then, by using purposive sampling technique, 74 students at the sixth semester students were chosen as the samples. Those students were given a questionnaire which contained question about motivation, perceptions and ability in English learning. There were 30 questions in at questionnaire. After the data were taken, it was processed by using frequency distribution to know how motivation and perception has influenced students' ability in learning English.

\section{RESULT AND DISCUSSION}

Based on the existing questionnaire data collection, the results are as follows:

1. Motivation

Related to the frequency distribution table about motivation, it can be seen from the following table:
Table 1. Motivation Category

\begin{tabular}{lcc}
\hline Motivation & Frequency & \% \\
\hline Negative & 34 & 45.9 \\
\hline Positive & 40 & 54.1 \\
\hline Total & 74 & 100 \\
\hline
\end{tabular}

From the table above it can be seen that from 74 students, 40 of them have positive motivation in learning English and 34 others lack of motivation. The difference in students who have positive and negative motivation is not too significant. Students have motivation in English but some of them lack motivation because of several factors. One of them is stated by Gardner and Gagne in Khalid (2017) who said that motivation in learning foreign languages can arise if the attitudes and culture of the people in the area support them to use that foreign language.

Furthermore, based on the research which was conducted by Fitriana (2018) of fourth grade of elementary school students, it was found that the motivation of students towards English learning was good. This is evidenced by $95 \%$ of students answering happy learning English. They stated that they were happy with the material being studied and felt familiar with what their teacher delivered in the classroom. It means that, based on that research, it can be concluded that basically students in the basic level were initially happy to learn English. However, the attitudes and culture that exists in the environment influence their motivation.

Furthermore, one of the cases revealed by (Rhepon, 2014)from interviews with several junior high school foster children found that most of them lacked motivation in learning English because they did not like the lesson. According to them English had a difficult vocabulary to memorize and the sentence composition is difficult to read. Therefore, they were not interested in learning English.

Based on those phenomena, it can be analyzed that basically, elementary school students has sufficient motivation to learn English. However, when they go to a higher level of junior high school they find difficulties such as the absence of an environment that supports them to use English in their daily communication. They do not feel confident and believe that English is not very useful in their everyday communication. Those problems cause a decrease in their motivation to learn English. It may continue until university level. Moreover, the attitude and culture in their environment will also influence their learning motivation.

\section{Perception}

One of the factors that determine the success of the teaching and learning process is the students' perception. From the results of data analysis, students' perceptions of learning English can be shown in the following table: 
Table 2. Perception Category

\begin{tabular}{lcc}
\hline Perception & Frequency & \% \\
\hline Poor & 47 & 63.5 \\
\hline Good & 27 & 36.5 \\
\hline Total & 74 & 100 \\
\hline
\end{tabular}

From the table above, it can be analyzed that from 74 students, 27 of them have a good perception in learning English. However, 47 of them had negative perception about English. Based on the questioner given, some of the students stated that they did not know English function related to their field of study. They thought that English is not really important for them.

This research is in line with (Aimah, 2018) who found that $42 \%$ of 38 high school students in SMAN 15 Semarang had a positive perception of learning English. They feel interested and want to learn English further. This can be proven by the fact that they were happy to give a response and feedback to the teacher when the material about English was delivered. In addition, student interest can also be judged by habits of the students outside learning, students can interact with the environment and encourage friends to learn English Basically, it is acknowledged that if students are interested in something, there is more enthusiasm to study about their interests. In conclusion, some students in SMA 15 Semarang were interested in learning English or they had a positive perception of English. It was proven by is the response they give about the learning process. They also tried to interact with their environment by using English.

Furthermore, based on (Mandefro, Mulatu, Abebe, \& Yona, 2016) research which examined the perceptions of students learning English in Sidama Zone, Ethiopia, from that study, $86.4 \%$ of students said that they had a perception that English was a language that was difficult to learn. However, they were trying to improve their abilities because they were confident and believe that speaking in English in various social contexts is needed.

Regarding the above research, it can be analyzed that most of the students have a lack perceptions in learning English. They assume that English is a language that is difficult to understand. However, they still try and improve their proficiency by giving a good response in the learning process and believe that English is an important language to learn. Students who have a good perception of learning English found it easy to complete their task in a subject or courses.

\section{Ability}

Ability is a determining component in observing the success of the teaching and learning process. If students can solve problems that are given it means that the learning process can be considered successful. Ability can be judged by the learner process either by the teacher or the students themselves. Students can evaluate their own abilities to what extent they understand something. After being given a questionnaire, the ability of students in learning English can be seen from the table below:
Table 3. Ability Category

\begin{tabular}{lcc}
\hline Ability & Frequency & \% \\
\hline Lack of ability & 38 & 51.4 \\
\hline Able & 36 & 48.6 \\
\hline Total & 74 & 100 \\
\hline
\end{tabular}

From the table above it can be drawn that from 74 students, 38 them said that they were less capable of mastering the skills in English. They think that they could not apply English learning in everyday life. They were still having difficulty listening, speaking, before writing in English.

This finding is in line with (Fallis, 2013) who argued that there were many students had lack the ability to hear what others say in English. They had a lot of difficulty in capturing what their interlocutors say when they speak English quickly so that they cannot understand what the other person is talking about. From this description, it can be concluded that the ability of Indonesian students to listen to their interlocutors speaking in English is still low.

According to (Artini, 2011)who found that $57.53 \%$ of students sometimes were unable to understand and respond to what their teacher explained in English. This affects their ability to write or do assignments. $63.01 \%$ of them stated that they could not complete their duties properly. From the results of this study it was found that students' ability to understand, respond and work on tasks was still lacking.

Furthermore, a study which was conducted by (Samarinda, 2018)found that students' ability to speak from year to year was still low. There were a number of things that occur when they talk such as stopping in the middle of talking, the duration of their talking was not long on average (under five minutes), limited vocabulary and no confidence when talking with their friends or teacher. From the research, it can be concluded that students' ability to speak was still limited and this decreases from year to year caused by several factors.

From some of the studies above and the results of the research obtained it can be assumed that the ability of students in English in listening, responding, speaking, reading or writing were lacking. It can be proven from several points of questions raised in this study. The respondents stated that they could understand English sometimes but not often. This phenomenon occurs due to several factors such as limited vocabulary, the speed of the person you are talking to and so on. This is also made worse by the unavailability of adequate facilities and environment for them to practice their English, both at school and at home. English is a day-to-day language that is used in that environment; the limited access to people who are able and willing to communicate in English greatly determines the students' language skills.

\section{CONCLUSION}

From the results of the research above, it can be concluded that the perceptions and motivations possessed by students greatly influence their abilities. From this study, it is noted that students' motivation and perceptions 
were lack in learning English so that it may have a big impact on their ability to use English; such as difficulties listening, reading, writing and responding in English. There are some factors that affect such attitudes and culture of the people in their environment and so on. It short, it can be concluded that most of the sixth semester students' in IAIN Bukittinggi unprepared to face international competitiveness because they do not have enough motivation and good perception in learning. It also affects their ability with speaking, writing, reading and listening in English. However, students must overcome their reluctance to study English in order to be prepared to be competitive globally.

\section{ACKNOWLEDGMENTS}

I would like to express my gratitude to almighty God - Allah SWT - who has given her the blessing, strength, health, opportunity and patience to finish this research. Besides, this research would not be finished without any support, guidance and valuable advices from many people. Therefore, the researchers would like to express her deepest appreciation and thankfulness to Ns. Yelmi Reni Putri, S.Kep, MAN as her contribution to give the suggestion about questioners' indicator. Then, for Cici Apriza Yanti as the head of Research and Dedication to Community Department who allowed us to conduct this research. Then, Dean of Guide and Counseling Study Program in IAIN Bukittinggi who had permitted and facilitated the researcher in conducting her research and also all of students at sixth semester of Guide and Counseling Study Program who have cooperated so well as respondents while this research being conducted. Last, but not the least for all of family member especially to mother and father who always support and pray to the researcher to do the best things in this life.

\section{REFERENCES}

[1] Aimah, S. (2018). Persepsi Siswa Terhadap Materi pembelajaran Bahasa Inggris Peminatan pada Siswa SMA N 15 Semarang, 1, 522-527.

[2] Arslan, N., \& Tathdil, H. (2012). Defining and Measuring Competitiveness: A Comparative Analysis of Turkey With 11 Potential Rivals. International Journal of Basic \& Applied Sciences, 12(2), 31-43.

[3] Artini, L. (2011). Persepsi guru dan siswa terhadap penggunaan bahasa Inggris di kelas bilingual di sekolah menengah atas berstatus RSBI di Bali. Jurnal Ilmu Pendidikan, 17(4), 307-312. Retrieved from http://journal.um.ac.id/index.php/jip/article/viewA rticle/2733

[4] Fallis, a. (2013). 済無No Title No Title. Journal of Chemical Information and Modeling, 53(9), 16891699. https://doi.org/10.1017/CBO9781107415324.004
[5] Fitriana, Rahmawati. 2018. Minat dan Motivasi dalam Belajar Bahasa Inggris SiswaKelas IV Sekolah Dasar di Kota Samarinda. Jurnal SNITTPoliteknik Negeri Balik Papan

[6] Kesehatan, M. (2010). Persepsi Mahasiswa Tentang Kepribadian Dan Kemampuan Dosen Dalam Mengajar Dengan Motivasi Belajar Mahasiswa Akademi. Core.Ac.Uk. Retrieved from http://core.ac.uk/download/pdf/12349172.pdf

[7] Mandefro, E., Mulatu, M., Abebe, T., \& Yona, Y. (2016). Perception of students and English Language teachers towards English Language Instruction: The case of schools in Sidama Zone, Ethiopia . International Journal of Humanities and Social Sciences, 8(June), 1-9.

[8] Muhfiyanti, Siti Aimah. 2018. Persepsi Siswa Terhadap Materi pembelajaran Bahasa Inggris Peminatan pada Siswa SMA N 15 Semarang. Prosiding Seminar Nasional Mahasiswa, Unimus. Vol 1

[9] Pendahuluan, a. (n.d.). Di Perguruan Tinggi Islam Dalam Konteks Esp ( English for Spesific Purpose ), 205-218.

[10] Reddy, M. S. (2016). Importance of English Language in today, $\mathrm{s}$ World Introduction : International Journal of Academic Research, 3(4), 181-182. Retrieved from http://www.google.com/url?sa=t\&rct=j\&q=\&esrc $=$ s\&source $=$ web\&cd $=1 \& v e d=2$ ahUKEwiHq8_k2 YTdAhXKuo8KHU5fDN4QFjAAegQIABAC\&ur l=http $\% 3 \mathrm{~A} \% 2 \mathrm{~F} \% 2 \mathrm{Fijar} .0 \mathrm{rg}$. in $\% 2 \mathrm{Fstuff} \% 2 \mathrm{Fissues}$ \%2Fv3-i4\%282\%29\%2Fv3-i4\%282\%29a021.pdf\&usg=AOvVaw11GZ_AkJeBFW9Z_ZHt omwi

[11] Rhepon, S. (2014). Upaya Meningkatkan Motivasi Belajar Bahasa Inggris Melalui Media Brosur Bimbingan Belajar dan Diskusi Kelompok pada Siswa SMP. PSIKOPEDAGOGIA Jurnal Bimbingan Dan Konseling, 3(1), 29. https://doi.org/10.12928/psikopedagogia.v3i1.446 3

[12] Sahlberg, P. (2006). Education reform for raising economic competitiveness. Journal of Educational Change, 7(4), 259-287. https://doi.org/10.1007/s10833-005-4884-6

[13] Samarinda, P. N. (2018). p-35 Minat dan Motivasi Dalam Belajar Bahasa Inggris Siswa Kelas IV Sekolah Dasar Di Kota Samarinda Interest And Motivation In Learning English At The Fourth Grade Students In Elementary School In Samamarinda.

[14] Santosa, R. B. (2018). Motivasi Dalam Pembelajaran Bahasa Inggris: Studi Kasus Pada Mahasiswa Jurusan Pendidikan Bahasa Inggris IAIN Surakarta. Jurnal Ilmiah Didaktika, 18(1), 87. https://doi.org/10.22373/jid.v18i1.3089 